\title{
Photobiomodulation with Single and Combination Laser Wavelengths on Bone Marrow Mesenchymal Stem Cells: Proliferation and Differentiation to Bone or Cartilage
}

\author{
Reza Fekrazad ${ }^{\# 1}$, Sohab Asefi ${ }^{2}$, Mohammadreza Baghban Eslaminejad ${ }^{\# 3}$, Leila Taghiar $^{2}$, \\ Sima Bordbar ${ }^{2}$, and Michael R Hamblin $4,5,6$ \\ ${ }^{1}$ Periodontics Department, Dentistry School, Laser Research Center in Medical Sciences, AJA \\ University of Medical Sciences, Tehran, Iran. \\ ${ }^{2}$ Orthodontic Department, Dentistry School, International Campus of Tehran University of Medical \\ Sciences, Tehran, Iran. \\ ${ }^{3}$ Department of Stem Cells and Developmental Biology, Royan Institute for Stem Cell Biology and \\ Technology, ACECR, Tehran, Iran \\ ${ }^{4}$ Wellman Center for Photomedicine, Massachusetts General Hospital, Boston, MA 02114, USA \\ ${ }^{5}$ Department of Dermatology, Harvard Medical School, Boston, MA 02115, USA \\ ${ }^{6}$ Harvard-MIT Division of Health Sciences and Technology, Cambridge, MA 02139, USA. \\ \# These authors contributed equally to this work.
}

\section{Abstract}

Background: Tissue engineering aims to take advantage of the ability of undifferentiated stem cells to differentiate into multiple cell types to repair damaged tissue. Photobiomodulation uses either lasers or light-emitting diodes to promote stem cell proliferation and differentiation. The present study aimed to investigate single and dual combinations of laser wavelengths on mesenchymal stem cells (MSCs).

Materials and Methods: MSCs were derived from rabbit iliac bone marrow. One control and 8 laser irradiated groups were designated as: Infra-red (IR, 810nm), Red (R, $660 \mathrm{~nm})$, Green (G, 532 $\mathrm{nm}$ ), Blue (B, $485 \mathrm{~nm}$ ), IR-R, IR-B, R-G, B-G. Irradiation was repeated daily for 21 days and cell proliferation, osseous or cartilaginous differentiation was then measured. RT-PCR biomarkers were SOX9, aggrecan, COL 2 and COL 10 expression for cartilage and ALP, COL 1 and osteocalcin expression for bone.

Results: Cellular proliferation was increased in all irradiated groups except G. All cartilage markers were significantly increased by IR and IR-B except COL 10 which was suppressed by IR$\mathrm{B}$ combination. ALP expression was highest in $\mathrm{R}$ and IR groups during osseous differentiation. ALP was decreased by combinations of IR with B and with R. and also by $G$ alone. R and B-G

correspondence Reza Fekrazad, rezafekrazad@gmail.com.

Conflict of interest

The authors declare no conflict of interest 
groups showed stimulated COL 1 expression, however COL 1 was suppressed in IR-B, IR-R and G groups. IR significantly increased osteocalcin expression, but in B, B-G and G groups it was reduced.

Conclusion: Cartilage differentiation was stimulated by IR and IR-B laser irradiation. The effects of single or combined laser irradiation were not clear-cut on osseous differentiation. Stimulatory effects on osteogenesis were seen for R and IR lasers, while G laser had inhibitory effects.

\section{Keywords}

photobiomodulation; low level light therapy; mesenchymal stem cells; bone; cartilage; comparison of wavelengths

\section{Introduction:}

Tissue engineering involves the addition, stimulation, differentiation, and guiding of cells with the goal of reconstructing impaired or damaged tissues. Three critical factors play significant role in a successful tissue regeneration; cells, scaffolds and signaling mediators such as growth factors. Stem cells are widely used in tissue engineering $(1,2)$. These cells have an infinite capacity for self-renewal, and can differentiate to various different types of target tissue depending on the cues they are exposed to (3). Mesenchymal stem cells (MSCs) are multipotent undifferentiated cells which can be harvested from many different tissues. Bone marrow is one of the most important sources for the harvest of MSCs (4). Bone marrow MSCs (BMSCs) are a heterogenous population with a high capacity for replication. They are pluripotent stem cells which can differentiate into osteoblasts, chondroblasts, adipocytes etc $(3,4)$. BMSCs are being investigated to treat pediatric high risk leukemia, osteogenesis imperfecta, mucopolysaccharidosis, graft-versus-host disease, myocardial infarction, immune deficiencies and metabolic disorders $(3,5,6)$. As mentioned above, MSCs have a critical role to play in tissue engineering procedures. The proliferation and differentiation of MSCs can, to some extent, be considered to be separate programmable processes, and controlling these processes in a predictable manner is crucial to satisfactory regeneration of the desired tissue type to be replaced or repaired.

Photobiomodulation (PBM) describes the use of lasers or light-emitting diodes (LEDs) to stimulate, repair and regenerate cells or tissues $(7,8)$. The PBM effects depend on the absorption of photons by chromophores within cells or tissues. This can be influenced by parameters like wavelength, energy density, mode of irradiation, etc. The wavelength of lasers used in PBM can range from 400 to $1100 \mathrm{~nm}$, which covers the whole spectrum from visible blue to invisible infrared. "PBM therapy" is the new and more accurate term for what was formerly known as "low level light therapy" (LLLT). This term was added to the Medical Subject Headings (MeSH) database in 2016. PBM can be defined as: "a nonthermal process involving endogenous chromophores eliciting photophysical (i.e., linear and nonlinear) and photochemical events at various biological scales" (9). PBM can promote or suppress specific cellular process such as proliferation or differentiation depending on the dose (biphasic dose response). PBM can act as a physical stimulus, which can promote or inhibit signaling mechanisms concerned with growth factor activity and cellular metabolic 
activities. Different laser wavelengths with different energy densities or targeting different chromophores, can initiate various cellular responses. Therefore a combination of lasers may produce novel effects on cell proliferation and differentiation compared to using single wavelengths alone. Our goal was to compare single lasers with four different wavelengths, with combinations using two different wavelengths, looking at the proliferation of MSCs and their differentiation into bone or cartilage. We chose to use rabbit MSCs because a future study would investigate PBM in an animal model constructed in rabbits.

\section{Materials and Methods:}

\section{Materials and Methods}

\section{Isolation and culture of rabbit mesenchymal stem cells (rMSCs)-Animal} experiments were carried out under a protocol (10) approved by the IACUC of Royan Institute for Stem Cell Biology and Technology. MSCs were isolated from rabbit bone marrow following a detailed protocol described previously (11). Briefly, 8 to 12 month-old rabbits were anesthetized by intramuscular injection of $50 \mathrm{mg} / \mathrm{kg}$ ketamine hydrochloride (100 mg/mL, Alfasan, Woerden-Holland) and $10 \mathrm{mg} / \mathrm{kg}$ xylazine hydrochloride $(20 \mathrm{mg} / \mathrm{mL}$, Alfasan, Woerden-Holland). After shaving and disinfecting the region, almost $3 \mathrm{~mL}$ of bone marrow was aspirated from the humerus of the animals using a Jamshidi aspiration needle and a $10 \mathrm{~mL}$ syringe containing $3000 \mathrm{U}$ of heparin. All procedures were carefully performed under sterile conditions to avoid bacterial infection of the samples. The marrow was slowly flushed out of the bones and suspended in Dulbecco's modified Eagle's medium (DMEM, Invitrogen, USA) supplemented with $15 \%$ fetal calf serum (FCS; Gibco), 100U/ml penicillin (Sigma) and $100 \mathrm{mg} / \mathrm{ml}$ streptomycin. The mononuclear cell fraction was plated in a $75 \mathrm{~cm}^{2}$ culture flask and incubated at $37^{\circ} \mathrm{C}$ in a humidified atmosphere of $5 \% \mathrm{CO}_{2}$ for 3 weeks. Cells were subsequently expanded through several passages and cells at passage 3 were used for the experiments. For the experiments the cells were seeded at low density.

\section{Cell proliferation (MTT) assay}

To measure and compare the proliferation rates of cells, $5 \times 10^{4}$ cells from each group (passage 2-3) were cultivated in $10 \mathrm{~cm}^{2}$ plastic dishes for 10 days to measure the foldincrease in cell number. The MTT assay was used to measure the proliferation capacities of the cells in each groups, the medium was exchanged with $300 \mathrm{~mL}$ of fresh DMEM and 20 $\mu \mathrm{L}$ of MTT solution $(5 \mathrm{mg} / \mathrm{mL})$. Cells were then incubated at $37^{\circ} \mathrm{C}$ for $2-3 \mathrm{~h}$ then the supernatant was discarded and $200 \mu \mathrm{L}$ of dimethyl sulfoxide (DMSO, Sigma, Germany) was subsequently added. Absorbance was recorded at $540-630 \mathrm{~nm}$. The rates of cell growth were calculated by constructing growth curves.

\section{Assessment of rMSCs differentiation}

MSCs were evaluated for their capacity to differentiate to cells from the skeletal lineage (i.e. osteoblasts, chondrocytes and adipocytes). Based on the literature, complete osteogenesis includes two phases, an early and a late phase. The early phase comprises ECM secretion, and the later phase comprises mineralization. These are complete at approximately 3 weeks. Therefore we collected our cells after 3 weeks of differentiation to ensure that osteogenesis was complete. rMSCs were trypsinized and seeded in 6-well culture plates. Osteogenic 
differentiation was induced by incubating the cells in osteogenic culture medium (DMEM supplemented with $10 \%$ FBS, $10 \mathrm{mM} \beta$ - glycerophosphate, $0.2 \mathrm{mM}$ ascorbic acid and $1 \mathrm{nM}$ dexamethasone) for 3 weeks. Osteogenesis was examined using $1 \%$ Alizarin red staining (Sigma). For adipogenic differentiation, the culture media was exchanged to adipogenic inductive medium containing DMEM supplemented with 10\% FBS, $0.5 \mathrm{mM}$ indomethacin, 1 $\mathrm{mM}$ ascorbic acid and $1 \mu \mathrm{M}$ dexamethasone, for 21 days. Lipid droplets in the cells were visualized by oil red $\mathrm{O}$ staining solution (Sigma). A micro mass culture system was used to induce chondrogenic differentiation of MSCs as previously described (12). Briefly, about $2.5 \times 10^{5}$ passage- 3 MSCs were pelleted under $1200 \mathrm{~g}$ for 5 minutes and cultured in chondrogenic medium (Lunza, Switzerland) for 21 days at $37{ }^{\circ} \mathrm{C}, 5 \% \mathrm{CO}_{2}$; with medium changed twice weekly. Chondrogenic differentiation was assessed by toluidine blue staining of pellets.

\section{Photobiomodulation Therapy}

PBM for bone and cartilage differentiation was initiated at $\mathrm{t}=0$ (time of differentiation) and then continued every other day for 3 weeks. Different wavelengths of visible and infrared diode laser light in continuous emission mode all at the same fluence of $4 \mathrm{~J} / \mathrm{cm} 2$ per session were used.

\section{Lasers}

Infrared (IR) $810 \mathrm{~nm}$ (THOR Photomedicine Ltd. UK); Red (R) $660 \mathrm{~nm}$ (THOR Photomedicine Ltd.); Green (G) 532 nm (LASER SYSTEM Ltd., Iran), Blue (B) $485 \mathrm{~nm}$ ((LASER SYSTEM Ltd.). and combination groups included IR-R, IR-B, R-G and B-G. The illumination time for each group considering the power and irradiation area to produce the same $4 \mathrm{~J} / \mathrm{cm}^{2}$ were: IR: $3 \mathrm{sec}$, R: $24 \mathrm{sec}, \mathrm{G}: 15 \mathrm{sec}$ and B: 15 . Lasers were irradiated sequentially and the order of irradiation was as specified in the group name, for example in IR-R group, cells were irradiated first by IR laser and then by R laser. Combination groups received $4 \mathrm{~J} / \mathrm{cm}^{2}$ of each wavelength for a total of $8 \mathrm{~J} / \mathrm{cm}^{2}$. The relevant parameters are given in Table 1.

\section{qRT-PCR measurement}

The expression level of osteogenic, chondrogenic and adipogenic related genes was evaluated using the qRT-PCR technique. Total RNA was extracted from cells using TRI Reagent ${ }^{\circledR}$ (Sigma-Aldrich, T9424). cDNA was produced by the RevertAid First Strand cDNA Synthesis Kit (Fermantas, K1632) according to the manufacturer's instructions.

Duplicate qRT-PCR reactions were performed with the SYBR Green Master Mix (Applied Biosystems Life Technologies, Inc., REF 4367659) with a real-time PCR system (Applied Biosystems ABI Step one plus) and analyzed with Step one software (Applied Biosystems; Step one software version 2.1). The samples were taken from three independent biological replicates. The expression level of target genes was normalized to GAPDH as a reference gene. Analysis was performed by the comparative $\Delta \Delta \mathrm{CT}$ method. Primer sequences are listed in Table 2. 


\section{Statistical analysis}

Statistical analyses were carried out on datasets consisting of at least three independent experiments, using an unpaired Student's $t$ test comparing two groups and one way ANOVA for comparing all groups together; with GraphPad Prism software (GraphPad, San Diego, CA, USA). All data are expressed as the mean \pm SD.

\section{Results:}

\section{Characteristics, morphology and proliferation of rMSCs}

Plastic-adherent cells with a typical fibroblastoid-like shape were isolated and expanded from bone marrow of rabbits (Fig. 1). The initial colonies from rMSCs appeared within two to five days after plating

\section{Differentiation potential of rMSCs into skeletal lineage}

To confirm the phenotype of isolated rMSCs and their differentiation into the two branches of the skeletal lineage, we assessed both histopathological staining and qRT-PCR gene expression. Differentiation of MSCs to the osteoblastic lineage was measured by alizarin red staining and qRT-PCR. The alizarin red results confirmed the presence of calcium minerals in the extracellular matrix of rMSCs. Mineral deposition started at day 5 and increased progressively up to day 21 (Fig. 2A, a). Real time PCR analysis of osteogenic related genes indicated that there were significant differences in the expression levels of the COL 2, OCN and OPN genes in rMSCs before and after differentiation (Fig 2B, a). Oil red $\mathrm{O}$ staining and qRT-PCR established adipogenic differentiation of rMSCs. Oil droplets were observed in the cytoplasm of differentiated cells after 3 weeks of culture (Fig. 2A, c). Analysis of adipogenic-related genes such as Lpl, Ppar-G and adiponectin showed a highly significant expression level of these genes in differentiated MSCs compared to the control group (Fig. $2 \mathrm{~B}, \mathrm{c})$.

The ability of rMSCs to undergo chondrogenic differentiation was measured by toluidine blue staining and also by qRT-PCR of the COL 2, aggrecan and Sox 9 genes. After 21 days, toluidine blue-stained areas indicated the presence of sulfated proteoglycans in rMSCs (Fig. $2 \mathrm{~A}, \mathrm{~b})$. Analysis of genes involved in chondrogenesis showed that rMSCs expressed comparable level of COL 2and Sox9 (Fig. 2B, b).

\section{Cellular proliferation}

Cellular proliferation was evaluated after a period of 10 days (Fig 3). The B-G laser combination led to the highest increase in cellular numbers, while $\mathrm{G}$ laser alone decreased MSC proliferation, and B laser alone had no effect. There was no significant difference between control group and other groups except B-G group. R and IR lasers both increased cellular proliferation with $\mathrm{R}$ better than IR. Combination of IR laser with either $\mathrm{B}$ or $\mathrm{R}$ lasers increased cell proliferation. R-G combination increased cellular proliferation compared with control, but to a lesser extent than $\mathrm{R}$ laser alone. A suppressive effect of $\mathrm{G}$ laser may have led to this result. 


\section{Osteogenic differentiation}

Osteogenic differentiation requires maturation of the matrix and subsequent mineralization to initiate bone production. Alkaline phosphatase expression (ALP) increases immediately after cellular proliferation. In the mineralization stage, osteocalcin expression increases. Alkaline phosphatase (ALP) was increased by all laser groups except G, IR-B and IR-R (Fig 4). IR-B and IRR groups decreased ALP to the lowest level and G laser was next. IR-B, G groups showed a insignificant decrease in APL compared with control group, while IR-R combination did not show any significant difference. It appeared that IR combined with other wavelengths (R or B) decreased ALP expression despite an increase with IR alone. All other groups increased APL insignificantly. R laser increased APL (5 times higher than control), while IR laser was close (4.5 times). The expression levels of all the genes were remarkably similar whether measured at 12 days or at 24 days.

Figure 5 shows levels of collagen type 1 (COL 1) gene expression which is also expressed during osteogenic differentiation. Combinations of IR laser (IR-B, IR-R) and also G laser alone insignificantly suppressed COL 1 . There was no significant difference between IR-R and control groups. IR and B alone increased osteogenic differentiation, while $\mathrm{R}$ and $\mathrm{B}-\mathrm{G}$ increased COL 1 dramatically (21 and 16.5 times higher than control).

At the final stage of bone differentiation, osteocalcin is expressed. IR laser increased OCN expression at 24 days but not at 12 days (Fig 6). Besides that, the only significant changes were an increase with R-G and a decrease with $\mathrm{G}$ alone.

There were some similarities between the three markers. IR alone and $\mathrm{R}$ alone tended to show increases, while G alone, IR-R and IR-B showed decreases. Overall IR laser had a better effect from beginning to end, while $\mathrm{R}$ laser had a better effect at beginning.

\section{Chondrogenic differentiation.}

Overall the IR laser had highest stimulatory effect on chondrogenesis-related gene expression (Fig 7), and on COL 10 in particular. All laser groups had stimulatory effects on COL 10, except IR-R. IR, G, and B alone, and IR-B increased the other markers (SOX9, aggrecan and COL 2).

\section{Discussion:}

Tissue engineering is concerned with the repair or regeneration of damaged or diseased biological tissues. Three critical factors play a role in this regard: cells, scaffolds, and signaling molecules. Since satisfactory tissue repair requires the participation of many different cell types, an efficient way to accomplish this goal is to employ stem cells that can differentiate into many different daughter cells. MSCs are a common type of stem cell used in tissue engineering. These cells usually have low yield and do not have a high proliferative rate when cultured in vitro. This slow proliferation rate can hinder clinical applications, when procedures must wait for enough cells to be produced. Moreover, the differentiation of MSCs into target cell types in governed by a range of different cues or stimuli, such as various chemicals, growth factors, mild forms of cell stress, or physical interventions such as lasers or PBM. 
Many parameters can influence the response of cells to lasers or PBM. Besides the energy density, power density, mode of irradiation (continuous or pulsed), the most important single parameter is the wavelength. The focus of this study was to compare the effects of four different laser wavelengths on MSC proliferation and differentiation. Importantly we wished to test the combination of two different wavelengths, which has seldom been done before. It was decided to use the same fluence $\left(4 \mathrm{~J} / \mathrm{cm}^{2}\right)$ of each wavelength for a total of $8 \mathrm{~J} / \mathrm{cm}^{2}$ in the combination groups. This may have been an important factor considering the biphasic dose response that operates in $\operatorname{PBM}(13,14)$. It is possible that even if a beneficial effect of combining two different wavelengths did in fact exist, it may not have been apparent because the total dose of $8 \mathrm{~J} / \mathrm{cm}^{2}$ exceeded the peak of the combined dose response curve. In retrospect, it may have been preferable to use $2 \mathrm{~J} / \mathrm{cm}^{2}$ of each wavelength and to have kept the total dose the same $\left(4 \mathrm{~J} / \mathrm{cm}^{2}\right)$ in both the single and dual wavelength groups.

Overall, we found that the most effective laser wavelength for affecting both proliferation and differentiation of MSCs was IR closely followed by R. G was probably the worst single wavelength. Combinations of two wavelengths were generally less effective than either IR or $\mathrm{R}$ alone, and interestingly the IR-R combination appeared to be a lot worse. In some cases the B-G combination was better than either wavelength alone.

Green laser has been successfully used in treatment of vascular lesions like hemangioma $(15,16)$ and has also been used for tooth bleaching, oral soft tissue surgery or killing bacteria in root canals or periodontal lesions (17-19).

Merigo et al (20) evaluated G laser (potassium-titanyl-phosphate or KTP, 532nm) at $4 \mathrm{~J} / \mathrm{cm}^{2}$, three times a week) for osteogenic differentiation of mouse bone marrow stromal cells (BMSCs). They claimed that $\mathrm{G}$ laser had a positive effect in this regard which was in conflict with our results. They found that $\mathrm{G}$ laser had no effect on the cellular proliferation, which also was in contrast with our study that found suppression of proliferation. We found that $\mathrm{G}$ laser could suppress cellular proliferation and osteogenic differentiation, however it could promote chondrogenic differentiation.

In 2016, Soltani et al (21) showed that R and $\mathrm{G}$ lasers can increase proliferation of human umbilical cord matrix-derived mesenchymal stem cells (hUCM). G laser was more effective than $\mathrm{R}$ laser. This was also opposite to our results with $\mathrm{G}$ laser, however the cell types were different. In agreement with our results, Wang and colleagues (22) showed that B (415 nm) and $\mathrm{G}(540 \mathrm{~nm})$ lasers inhibited proliferation of human adipose derived stem cells (hASCs), while R $(660 \mathrm{~nm})$ and IR $(810 \mathrm{~nm})$ lasers stimulated proliferation. They also found that B and $\mathrm{G}$ lasers were better than R and IR lasers for stimulating differentiation of hASCs into osteogenic lineage cells (23). This is in partial agreement and partial disagreement with the present results.

Our results suggest that if it is desired to achieve differentiation into cartilage without any osteogenic differentiation, $\mathrm{G}$ laser would be the preferred wavelength.

In a literature review by Amid et al in 2014 (24) and a systematic review by Ginani et al (25), the stimulatory effect of R and IR lasers was confirmed on both proliferation and osteogenic differentiation of stem cells. This was in agreement with our results. By contrast, 
Renno et al. (26) showed a single exposure of $830 \mathrm{~nm}$ IR laser at $10 \mathrm{~J} / \mathrm{cm} 2$ fluence, inhibited osteoblast proliferation compared to control group. Bouvet- Gerbettaz et al. (27) showed that exposure of IR laser $(808 \mathrm{~nm})$ at $4 \mathrm{~J} / \mathrm{cm}^{2}$ three times a week did not alter proliferation and differentiation of murine bone marrow stem cells. (Table-2). In a comparative study, Wang and colleagues (28) found that hASCs had better osteogenic differentiation by B $(420 \mathrm{~nm})$ and $\mathrm{G}(540 \mathrm{~nm})$ lasers than R $(660 \mathrm{~nm})$ or IR $(810 \mathrm{~nm})$.

We were not able to find any studies on PubMed database about combination of different laser wavelengths on MSCs differentiation either to chondrocytes or osteoblasts in-vitro. Moreover there were no pre-clinical or clinical studies either. There have been a few studies on combination laser wavelengths used for treatment of skin disorders like wound healing in bacterially contaminated cutaneous wounds (29), or in psoriasis (30). These studies generally used a combination of $\mathrm{R}$ and IR lasers. They concluded that combination laser therapy could be an improvement in anti-inflammatory effects and wound healing compared to single wavelengths (31). Our study is probably the first to evaluate the effect of a combination of different laser wavelengths on MSC proliferation and differentiation. Combination of IR-R suppressed collagenous differentiation, while IR alone can stimulated it. R-G combination stimulated cartilage formation although $\mathrm{G}$ laser alone had a better effect than combined therapy. R and IR lasers alone each stimulated osteogenic differentiation, however IR-R combination suppressed it.

\section{Conclusion:}

Our results show that R and IR lasers stimulated the proliferation of rabbit BMSCs and modulated differentiation into bone and cartilage. The $\mathrm{G}$ laser inhibited cell proliferation and osseous differentiation while it stimulated cartilagenous differentiation. Combination lasers had different effects that could not be predicted from the effects of each wavelength alone. It is possible that the combined laser fluences exceeded the peak of the biphasic dose response.

\section{Acknowledgement}

AJA University of Medical Sciences and Rouyan Institute supported this study. MRH was supported by US NIH grants R01AI050875 and R21AI121700.

\section{Reference:}

1. Egusa H, Sonoyama W, Nishimura M, Atsuta I, K. A. Stem cells in dentistry-part I: stem cell sources. Journal of prosthodontic research. 2012 56(3):151-65. [PubMed: 22796367]

2. Otsu K, Kumakami-Sakano M, Fujiwara N, Kikuchi K, Keller L, Lesot H, et al. Stem cell sources for tooth regeneration: current status and future prospects. Frontiers in physiology. 2014;5.

3. Egusa H, Sonoyama W, Nishimura M, Atsuta I, Akiyama K. Stem cells in dentistry - Part I: Stem cell sources. Journal of Prosthodontic Research. 2012;56:151-65. [PubMed: 22796367]

4. Pittenger MF, Mackay AM, Beck SC, Jaiswal RK, Douglas R, Mosca JD, et al. Multilineage potential of adult human mesenchymal stem cells. science. 1999;284(5411):143-7. [PubMed: 10102814]

5. Shand J, Berg J, Bogue C, Denne SC, Bauer AJ, Cabana MD, et al. Human Embryonic Stem Cell (hESC) and Human Embryo Research. Pediatrics. 2012;130(5):972-7. [PubMed: 23109685]

6. AlGhamdi Kh.M., Kumar A, Moussa NA Low-level laser therapy: a useful technique for enhancing the proliferation of various cultured cells. Lasers Med Sci. 2012;27:237-49. [PubMed: 21274733] 
7. Fekrazad R, Eslaminejad MB.A.M S, Kalhori KA, Abbas FM, Taghiar L, et al. Effects of photobiomodulation and mesenchymal stem cells on articular cartilage defects in a rabbit model. Photomedicine and laser surgery. 2016;34(11):543-9. [PubMed: 27058019]

8. Fekrazad R, Asefi S, Allahdadi M, Kalhori KA. Effect of photobiomodulation on mesenchymal stem cells. Photomedicine and laser surgery. 2016;34(11):533-42. [PubMed: 27070113]

9. Anders JJ, Lanzafame RJ, Arany PR. Low-level light/laser therapy versus photobiomodulation therapy. Mary Ann Liebert, Inc 140 Huguenot Street, 3rd Floor New Rochelle, NY 10801 USA; 2015.

10. Fekrazad R, Sadeghi Ghuchani M, Eslaminejad MB, Taghiyar L, Kalhori KA, Pedram MS, et al. The effects of combined low level laser therapy and mesenchymal stem cells on bone regeneration in rabbit calvarial defects. J Photochem Photobiol B. 2015;151:180-5. [PubMed: 26298068]

11. Fekrazad R, Sadeghi Ghuchani M, Eslaminejad MB, Tghiyar L, Kalhor KAM, Pedram MS, et al. The effects of combined low level laser therapy and mesenchymal stem cells on bone regeneration in rabbit calvarial defects. Journal of Photochemistry and Photobiology B: Biology. 2015;151:1805.

12. Eslaminejad MB, Nikmahzar A, Taghiyar L, Nadri S, Massumi M. Murine mesenchymal stem cells isolated by low density primary culture system. Dev Growth Differ. 2006;48(6):361-70. [PubMed: 16872449]

13. Huang YY, Chen AC, Carroll JD, Hamblin MR. Biphasic dose response in low level light therapy. Dose Response. 2009;7(4):358-83. [PubMed: 20011653]

14. Huang YY, Sharma SK, Carroll JD, Hamblin MR. Biphasic dose response in low level light therapy - an update. Dose Response. 2011;9(4):602-18. [PubMed: 22461763]

15. Alster TS, D R. Laser treatment of vascular birthmarks. Journal of Craniofacial Surgery. 2006;17(4):720-3. [PubMed: 16877924]

16. Garden JM, AD B. Clinical efficacy of the pulsed dye laser in the treatment of vascular lesions. The Journal of dermatologic surgery and oncology. 1993;19(4):321-6. [PubMed: 8478471]

17. Merigo E, Bouvet-Gerbettaz S, Boukhechba F, Rocca JP, Fornaini C, N R. Green laser light irradiation enhances differentiation and matrix mineralization of osteogenic cells. Journal of Photochemistry and Photobiology B: Biology. 2016;155:130-6.

18. Nammour S, Rocca JP, Keiani K, Balestra C, Snoeck T, Powell L, et al. Pulpal and periodontal temperature rise during KTP laser use as a root planning complement in vitro. Photomedicine and Laser Therapy. 2005;23(1):10-4.

19. Romeo U, Palaia GBR, Leone V, Rocca JP, A P. Non-surgical periodontal therapy assisted by potassium-titanyl-phosphate laser: a pilot study. Lasers in medical science. 2010;25(6):891-9. [PubMed: 19936872]

20. Merigo E, Bouvet-Gerbettaz S, Boukhechba F, Rocca J-P, Fornaini C, Rochet N. Green laser light irradiation enhances differentiation and matrix mineralization of osteogenic cells. Journal of Photochemistry and Photobiology B: Biology. 2016;155:130-6.

21. Soltani SD, Babaee A, Shojaei M, Salehinejad P, Seyedi F, JalalKamali M, et al. Different effects of energy dependent irradiation of red and green lights on proliferation of human umbilical cord matrixderived mesenchymal cells. Lasers in medical science. 2016;31(2):255-61. [PubMed: 26714979]

22. Wang Y, Huang Y-Y, Wang Y, Lyu P, Hamblin MR. Red (660 nm) or near-infrared (810 nm) photobiomodulation stimulates, while blue $(415 \mathrm{~nm})$, green $(540 \mathrm{~nm})$ light inhibits proliferation in human adipose-derived stem cells. Scientific reports. 2017;7(1):7781. [PubMed: 28798481]

23. Wang Y, Huang YY, Wang Y, Lyu P, Hamblin MR. Photobiomodulation (blue and green light) encourages osteoblastic-differentiation of human adipose-derived stem cells: role of intracellular calcium and light-gated ion channels. Sci Rep. 2016;6:33719. [PubMed: 27650508]

24. Amid R, Kadkhodazadeh M, Ahsaie MG, Hakakzadeh A. Effect of Low Level Laser Therapy on Proliferation and Differentiation of the Cells Contributing in Bone Regeneration: A Systematic Review. Journal of lasers in medical sciences. 2014;5(4):163. [PubMed: 25653816]

25. Ginani F, Soares DM, Barboza CAG. Effect of low-level laser therapy on mesenchymal stem cell proliferation: a systematic review. Lasers in medical science. 2015;30(8):2189-94. [PubMed: 25764448] 
26. Renno A, McDonnell P, Crovace M, Zanotto ED, L L. Effect of $830 \mathrm{~nm}$ laser phototherapy on osteoblasts grown in vitro on Biosilicate scaffolds. Photomed Laser Surg. 2010;28(1):131-3. [PubMed: 19814702]

27. Bouvet-Gerbettaz S, Merigo E, Rocca JP, Carle GF, N R. Effects of low-level laser therapy on proliferation and differentiation of murine bone marrow cells into osteoblasts and osteoclasts. Lasers Surg Med 2009;41(4):291-7. [PubMed: 19347941]

28. Wang Y, Huang Y-Y, Wang Y, Lyu P, Hamblin MR. Photobiomodulation (blue and green light) encourages osteoblastic-differentiation of human adipose-derived stem cells: role of intracellular calcium and light-gated ion channels. Scientific reports. 2016;6:33719. [PubMed: 27650508]

29. Santos NR, de M. Sobrinho JB, Almeida PF, Ribeiro AA, Cangussú MC, dos Santos JN, et al. Influence of the combination of infrared and red laser light on the healing of cutaneous wounds infected by Staphylococcus aureus. Photomed Laser Surg. 2011;29(3):177-82. [PubMed: 21214389]

30. Ablon G Combination 830-nm and 633-nm light-emitting diode phototherapy shows promise in the treatment of recalcitrant psoriasis: preliminary findings. Photomed Laser Surg. 2010;28(1):141-6. [PubMed: 19764893]

31. de Lima F, Barbosa FT, de Sousa-Rodrigues CF. Use alone or in Combination of Red and Infrared Laser in Skin Wounds. Journal of lasers in medical sciences. 2013;5(2):51-7.

32. Bloise N, Ceccarelli G, Minzioni P, Vercellino M, Benedetti L, De Angelis MG, et al. Investigation of low-level laser therapy potentiality on proliferation and differentiation of human osteoblast-like cells in the absence/presence of osteogenic factors. Journal of biomedical optics. 2013;18(12): 128006-. [PubMed: 24365957]

33. Renno A, McDonnell P, Parizotto NA, EL L. The effects of laser irradiation on osteoblast and osteosarcoma cell proliferation and differentiation in vitro. Photomed Laser Surg. 2007;25(4):27580. [PubMed: 17803384]

34. Stein A, Benayahu D, Maltz L, U O. Low-level laser irradiation promotes proliferation and differentiation of human osteoblasts in vitro. Photomed Laser Surgery. 2005;23(2):161-6.

35. Wu Y, Wang J, Gong D, Gu H, Hu S, H Z. Effects of lowlevel laser irradiation on mesenchymal stem cell proliferation: a microarray analysis. Laser Med Sci 2012;27(2):509-19.

36. Li WT, Chen HL, CT W. Effect of light emitting diode irradiation on proliferation of human bone marrow mesenchymal stem cells. J Med Biol Eng 2006;26(1).

37. Hou JF, Zhang H, Yuan X, Li J, Wei YJ, SS H. In vitro effects of low-level laser irradiation for bone marrow mesenchymal stem cells: proliferation, growth factors secretion and myogenic differentiation. Lasers Surg Med 2008;40(10):726-33. [PubMed: 19065562]

38. Horvát-Karajz K, Balogh ZKV, HámoriDrrernat A, Sréter L, F U. In vitro effect of carboplatin, cytarabine, paclitaxel, vincristine, and low-power laser irradiation on murine mesenchymal stem cells. Lasers Surg Med 2009;41(6):463-9. [PubMed: 19588531]

39. Giannelli M, Chellini F, Sassoli C, Francini F, Pini A, Squecco R, et al. Mesenchymal stromal cells with diode laser: Effects and mechanisms of action. J Cell Physiol 2013;228(1):172-81. [PubMed: 22628164]

40. Wang J, Huang W, Wu Y, Hou J, Nie Y, Gu H, et al. MicroRNA-193 pro-proliferation effects for bone mesenchymal stem cells after low-level irradiation treatment through inhibitor of growth family,member 5. Stem Cells Dev 2012;21(13):2508-19. [PubMed: 22384930]

41. Migliario M, Pittarella P, Fanuli M, Rizzi M, F R. Laser-induced osteoblast proliferation is mediated by ROS production. Lasers Med Sci 2014;29(4):1463-7. [PubMed: 24595962]

42. Jawad M, Husein A, Azlina A, Alam MK, Hassan R, Shaari, et al. Effect of $940 \mathrm{~nm}$ low-level laser therapy on osteogenesis in vitro. J Biomed Opt 2013;18(12):128001. [PubMed: 24337495]

43. Hamajima S, Hiratsuka K, Kiyama-Kishikawa M, Tagawa T, Kawahara M, M O. Effect of lowlevel laser irradiation on osteoglycin gene expression in osteoblasts. Lasers Med Sci. 2003;18(2): 78-82. [PubMed: 12928816]

44. Tuby H, Maltz L, U O. Low-level laser irradiation (LLLI) promotes proliferation of mesenchymal and cardiac stem cells in culture. Lasers Surg Med 2007;39(4):373-8. [PubMed: 17457844] 
45. Soleimani M, Abbasnia E, Fathi M, Sahraei H, Fathi Y, G K. The effects of low-level laser irradiation on differentiation and proliferation of human bone marrow mesenchymal stem cells into neurons and osteoblasts: an in vitro study. Laser Med Sci. 2012;27(2):423-30.

46. Aleksic V, Aoki A, Iwasaki K, Takasaki AA, Wang CY, Y A. Low-level Er: YAG laser irradiation enhances osteoblast proliferation through activation of MAPK/ERK. Lasers Med Sci 2010;25(4): 559-69. [PubMed: 20186556] 

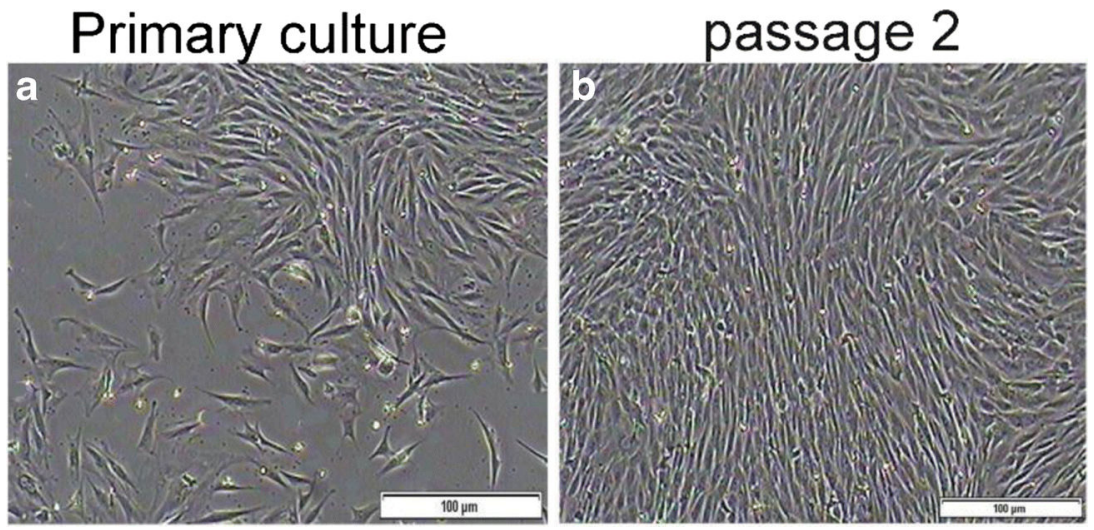

Fig 1.

Characterization of rMSCs. The figure shows the morphology of primary (a) and passage 2 culture (b) of bone marrow derived MSCs. 
a
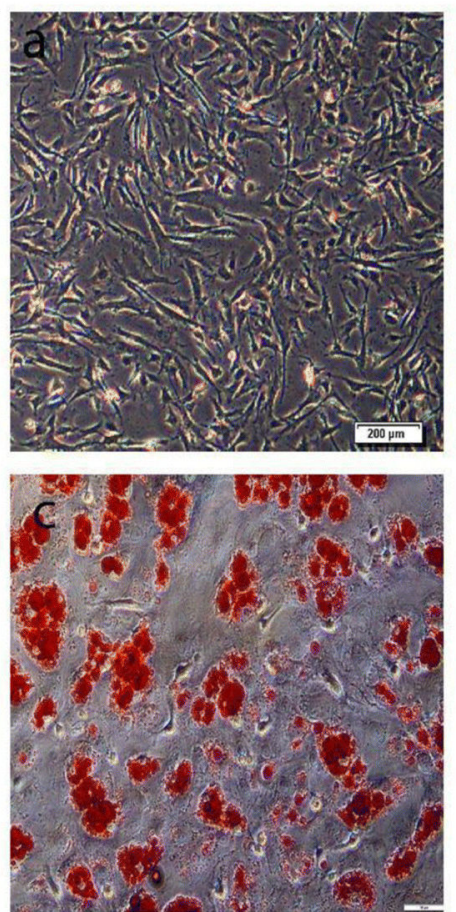
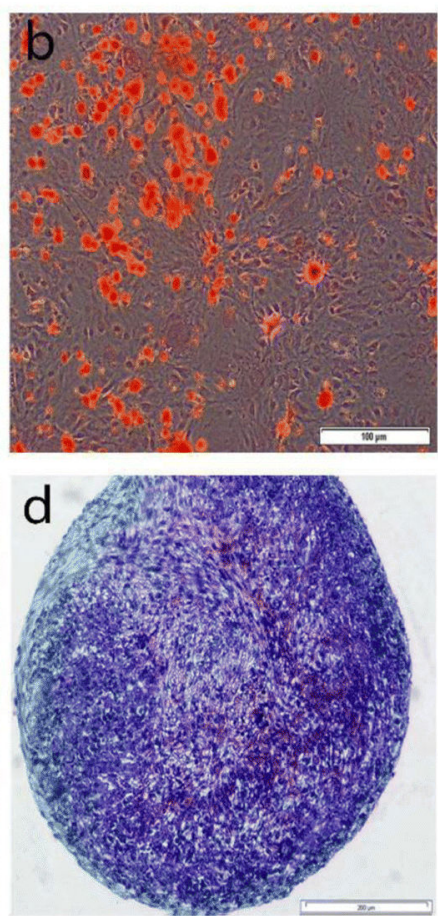

b

a

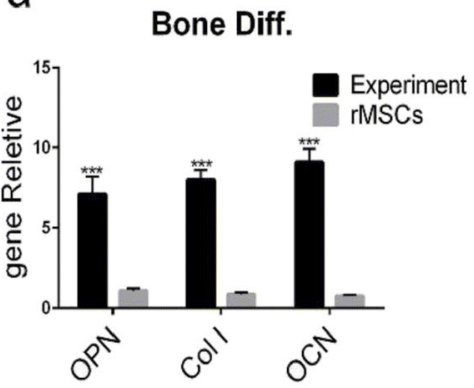

b Chondrogenic diff.

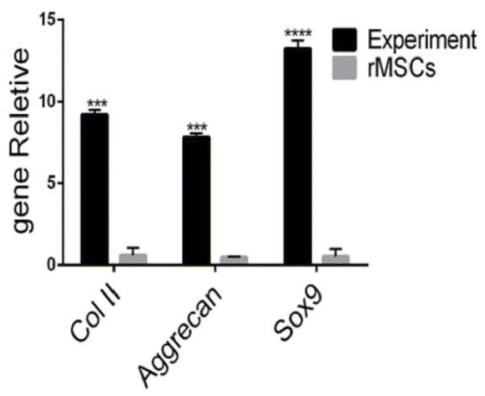

\section{C}

Adipogenic diff.

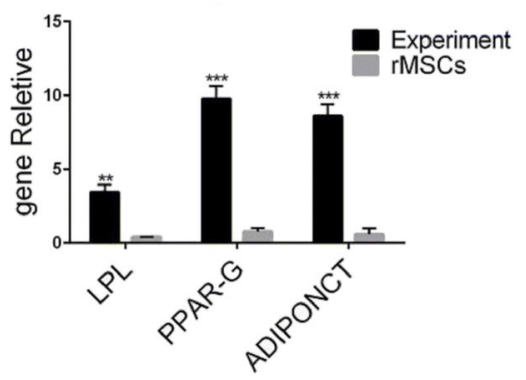

Fig 2. Differentiation potential of rMSCs into cells of skeletal lineages.

(A) The image shows differentiation potential of rMSCs to osteoblasts, chondrocytes and adipocytes. Undifferentiated rMSCs as a control group and differentiated cells as experimental groups. Control group (a); cells differentiated into osteoblasts stained with Alizarin red-S (b); cells differentiated into adipocytes stained with Oli red (c); and cells differentiated into chondroblasts stained with Toluidine blue (d). (B) qRT-PCR data of rMSCs differentiated to cells of skeletal lineage. qRT-PCR result for osteogenic differentiation (i.e. COL 1, OCN and OPN) (a), qRT-PCR result for chondrogenic differentiation (i.e. COL 2, Sox9 and aggrecan) (b) and qRT-PCR result for adipogenic differentiation (i.e. LPL, adiponectin and Ppar-G) (c) were obtained after 21 days. Data are presented as means $\pm \mathrm{SD}(\mathrm{n}=3)(\mathrm{P}<0.05)$ 


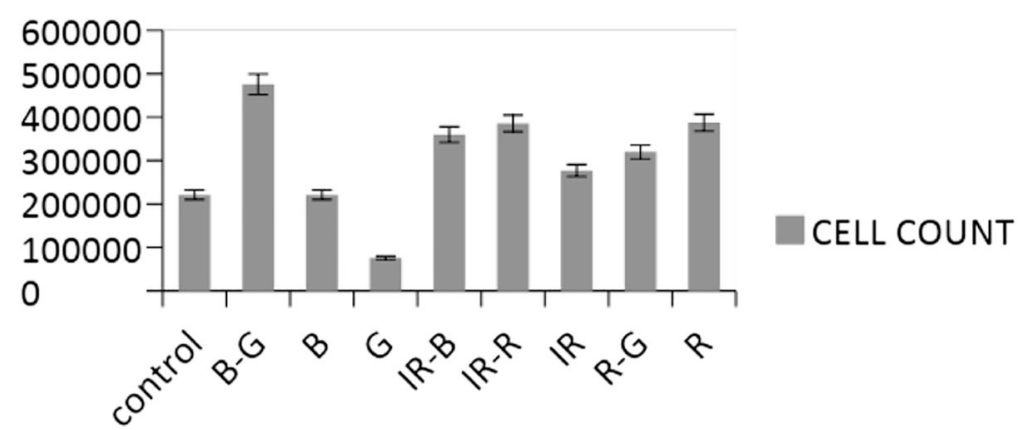

Fig 3.

Evaluation of rabbit BMSCs proliferation after laser irradiation during 10 days. Initial cell count was $50 \times 10^{3}$. B-G lasers combination increased cellular proliferation significantly compared to control group. $(\mathrm{P}<0.05)$ 


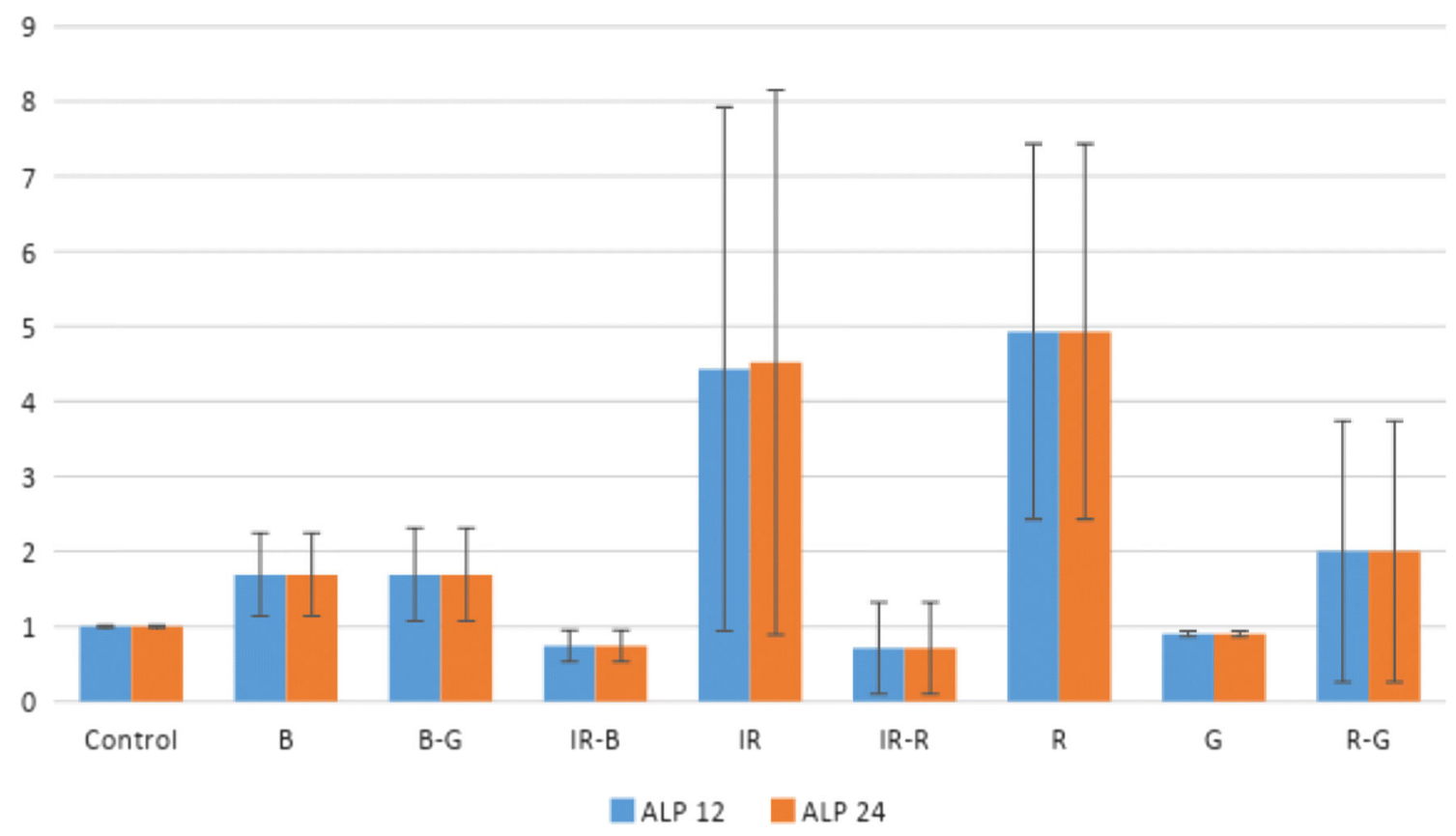

Fig 4.

Alkaline phosphatase gene expression after different laser irradiations during osseous differentiation (day 12 and 24). there was not any significant difference between groups. (P value $>0.05)$. Experiments were repeated 3 times. 


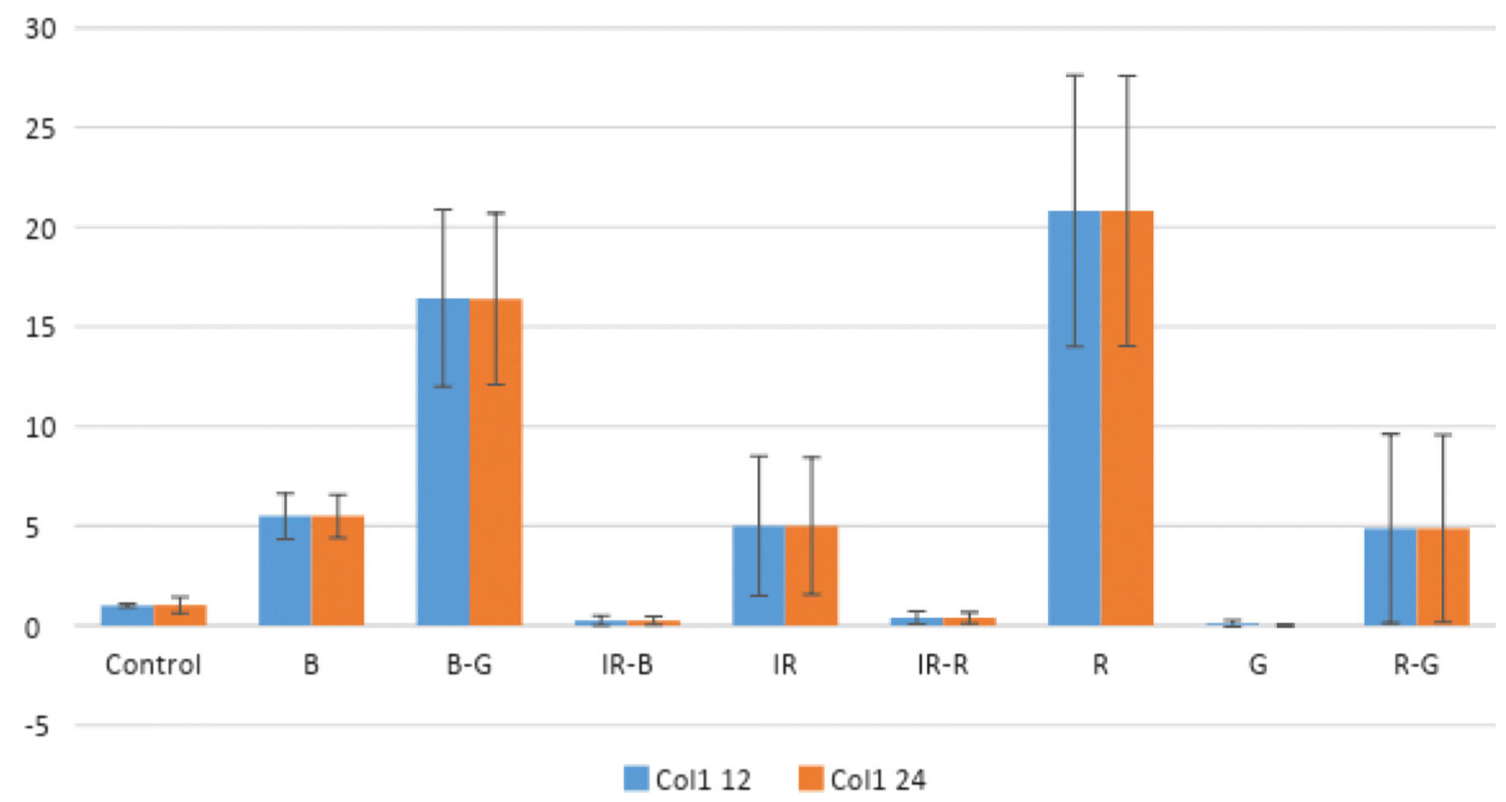

Fig 5.

Collagen type 1 gene expression after different laser irradiations during osseous differentiation (day 12 and 24). B-G and R laser groups had significant differences compared to control groups $(\mathrm{P}$ value $<0.05)$. Experiments were repeated 3 times. 


\section{6}

5

4

3

2

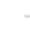

1

0

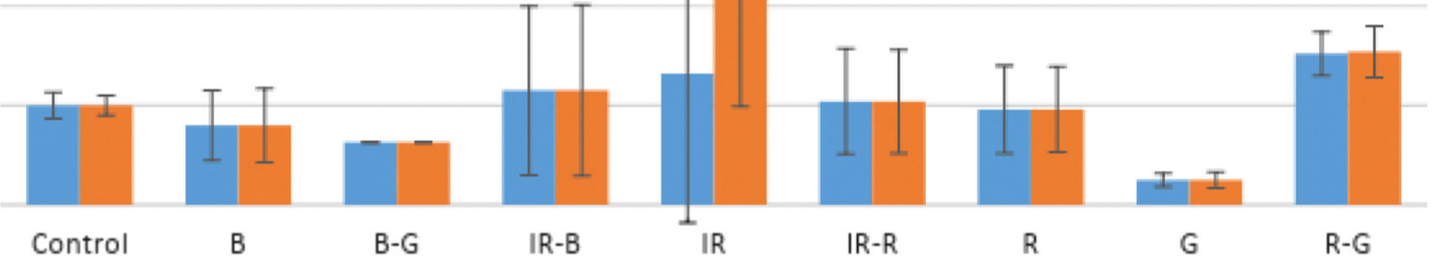

$-1$

OCN $12 \square$ OCN 24

Fig 6.

Osteocalcin gene expression after different laser irradiations during osseous differentiation (day 12 and 24). There were no significant difference between control group and other groups. ( $\mathrm{P}$ value $>0.05$ ). Experiments were repeated 3 times. 


$$
250
$$

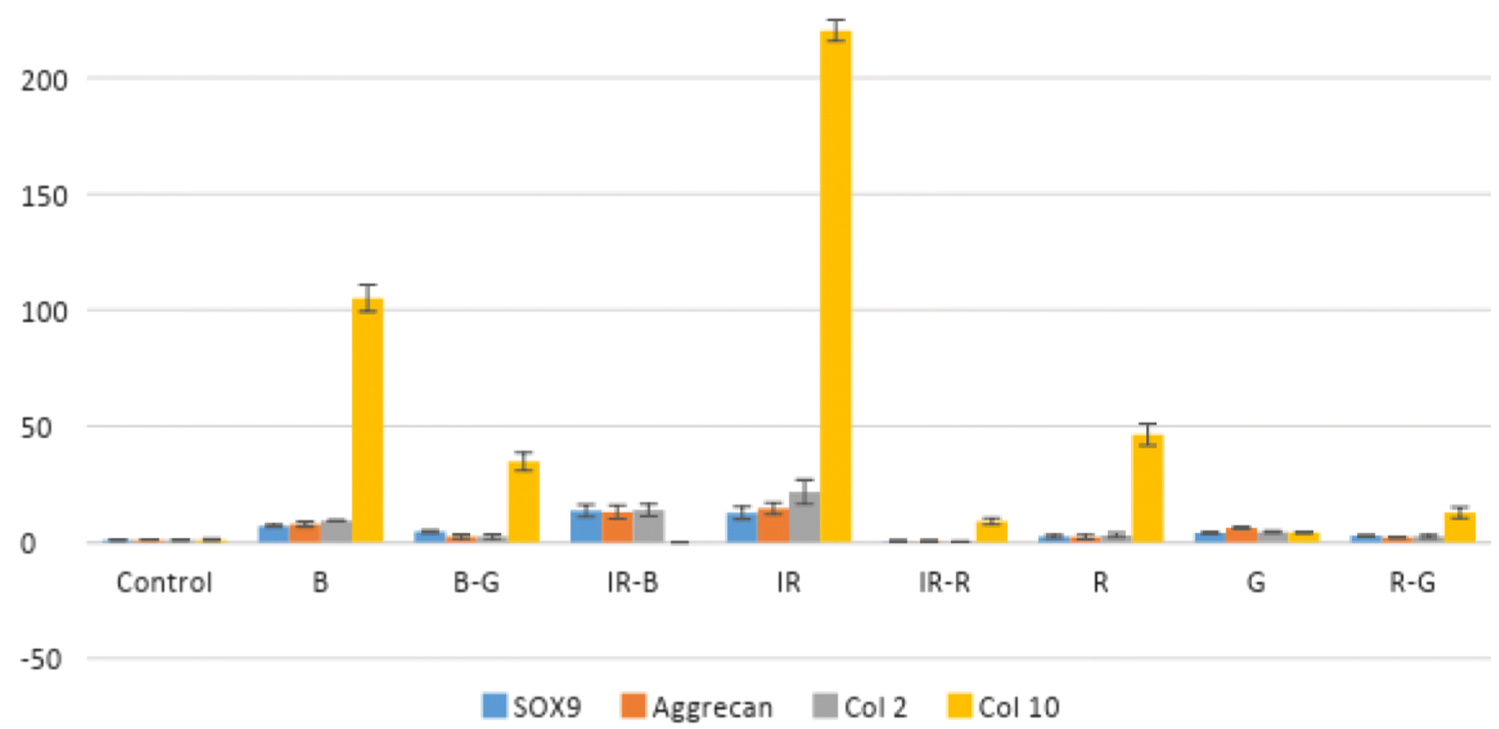

Fig 7.

Sox9, Aggrecan, COL 2 and COL 10 gene expression after different laser irradiations during osseous differentiation. IR, IR- B and B groups had significant differences in Sox9,

Aggrecan and COL 2 compared to control group. G group had significant difference in Aggrecan with control group. B, B-G IR and R groups had significant difference in COL 10 $(\mathrm{P}$ value $<0.05)$. Experiments were repeated 3 times. 
Table 1.

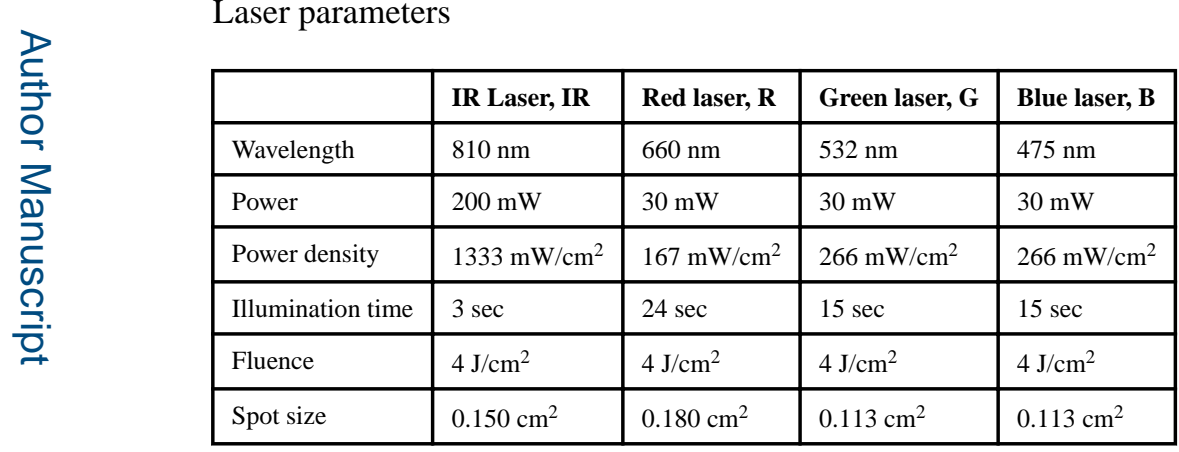


Table 2:

Description of rabbit primer sequences used in qRT-PCR.

\begin{tabular}{|c|c|c|c|c|}
\hline Gene & Gene symbol & Sequence $(5-3)$ & Annealing time $\left({ }^{\circ} \mathrm{C}\right)$ & Amplicon size (bp) \\
\hline \multirow[t]{2}{*}{ Osteocalcin } & \multirow[t]{2}{*}{$\mathrm{OCN}$} & $\begin{array}{l}\text { F: 5' ACA AGA GAT TCA GCG ACT } \\
3^{\prime}\end{array}$ & \multirow[t]{2}{*}{57} & \multirow[t]{2}{*}{126} \\
\hline & & $\begin{array}{l}\text { R: 5' GGT TCT TGG CTT CCT GTT } \\
\text { TC 3' }\end{array}$ & & \\
\hline \multirow[t]{2}{*}{ Collagen 1} & \multirow[t]{2}{*}{$\mathrm{COL} 1$} & $\begin{array}{l}\text { F: 5' GGT GCT GCT GGT AAA GAA } \\
\text { GG 3' }\end{array}$ & \multirow[t]{2}{*}{60} & \multirow[t]{2}{*}{245} \\
\hline & & $\begin{array}{l}\text { R: 5' GTC TAC CCA AAG CAC CAG } \\
3^{\prime}\end{array}$ & & \\
\hline \multirow[t]{2}{*}{ Alkaline phosphatase } & \multirow[t]{2}{*}{ ALP } & $\begin{array}{l}\text { F: 5' ACTTTGTCTGGAACCGCACT } \\
3^{\prime}\end{array}$ & \multirow[t]{2}{*}{58} & \multirow[t]{2}{*}{215} \\
\hline & & R: 5' GTGGTCAATCCTGCCTCCT 3' & & \\
\hline \multirow[t]{2}{*}{ Sex-determining region $\mathrm{Y}$ box 9} & \multirow[t]{2}{*}{ SOX9 } & F: 5' AAGATGACCGACGAGCAG 3' & \multirow[t]{2}{*}{60} & \multirow[t]{2}{*}{232} \\
\hline & & R: 5' GGCTTGTTCTTGCTGGAG 3' & & \\
\hline \multirow[t]{2}{*}{ Collagen 2} & \multirow[t]{2}{*}{$\mathrm{COL} 2$} & F: 5' GTGGAAGAGCGGTGACTA 3' & \multirow[t]{2}{*}{60} & \multirow[t]{2}{*}{250} \\
\hline & & R: 5' TAGGTGATGTTCTGGGAGC 3' & & \\
\hline \multirow[t]{2}{*}{ Aggrecan } & \multirow[t]{2}{*}{ Aggrecan } & $\begin{array}{l}\text { F: 5' } \\
\text { GGAGGTCGTGGTGAAAGGTG 3' }\end{array}$ & \multirow[t]{2}{*}{61} & \multirow[t]{2}{*}{255} \\
\hline & & $\begin{array}{l}\text { R: 5' } \\
\text { CAGAGGAGATGGAGGGTGAG 3' }\end{array}$ & & \\
\hline \multirow[t]{2}{*}{ Collagen 10} & \multirow[t]{2}{*}{ COL 10} & F: AGTTCTTCATTCCCTATGCCA & & \\
\hline & & R: CAATGTCTCCTTTCGGTCCA & & \\
\hline \multirow[t]{2}{*}{ Glyceraldehyde-3phosphate dehydrogenase } & \multirow[t]{2}{*}{ GAPDH } & $\begin{array}{l}\text { F: 5' CACCCACTCCTCTACCTTCG } \\
\text { 3' }\end{array}$ & \multirow[t]{2}{*}{57} & \multirow[t]{2}{*}{141} \\
\hline & & R: 5' GGTCTGGGATGGAAACTGTG & & \\
\hline
\end{tabular}


Table-2:

Literature review of PBM and LLLT on bone marrow stem cells.

\begin{tabular}{|c|c|c|c|c|c|c|}
\hline No & Author \& year & Type of laser & Type of irradiation & Type of cells & Criteria & Main results \\
\hline 1 & $\begin{array}{l}\text { Bloise et al. } \\
2013 \text { (32) }\end{array}$ & $659 \mathrm{~nm}$ & $\begin{array}{l}\text { Single transverse- } \\
\text { mode Power output: } \\
10 \mathrm{~mW} \text { Fluence: } 1 \text {, } \\
3 \mathrm{~J} / \mathrm{cm} 2\end{array}$ & $\begin{array}{l}\text { Human osteoblast- } \\
\text { like cell line (Saos- } 2 \\
\text { cell line) }\end{array}$ & Proliferation Differentiation & $\begin{array}{l}\text { LLLT } \\
\text { enhanced } \\
\text { Saos2 cells } \\
\text { proliferation } \\
\text { and } \\
\text { maturation. }\end{array}$ \\
\hline 2 & $\begin{array}{l}\text { Renno et al. } \\
\text { 2007(33) }\end{array}$ & $\begin{array}{l}\text { 670-nm, 780- } \\
\mathrm{nm} \text {, and 830- } \\
\mathrm{nm}\end{array}$ & $\begin{array}{l}\text { Single exposure } \\
\text { Power output: } 10 \\
\text { mW Fluence: } 0.5,1 \text {, } \\
5 \text {, and } 10 \mathrm{~J} / \mathrm{cm} 2\end{array}$ & $\begin{array}{l}\text { Neonatal, murine, } \\
\text { calvarial, } \\
\text { osteoblastic } \\
\text { (MC3T3) and human } \\
\text { osteosarcoma } \\
\text { (MG63) cell lines }\end{array}$ & $\begin{array}{l}\text { Cell proliferation Alkaline } \\
\text { phosphatase activity }\end{array}$ & $\begin{array}{l}\text { Cell lines } \\
\text { responded } \\
\text { differently to } \\
\text { specific } \\
\text { wavelength } \\
\text { and dose. } \\
\text { Osteoblastic } \\
\text { proliferation } \\
\text { and ALP } \\
\text { activity were } \\
\text { significantly } \\
\text { increased by } \\
830 \mathrm{~nm} \\
\text { wavelength at } \\
10 \mathrm{~J} / \mathrm{cm} 2\end{array}$ \\
\hline 3 & $\begin{array}{l}\text { Stein et al. } \\
2005(34)\end{array}$ & $\begin{array}{l}\text { He-Ne laser } \\
(632 \mathrm{~nm})\end{array}$ & $\begin{array}{l}\text { Power output: } \\
10 \mathrm{~mW} \text { Fluence: } \\
0.43 \mathrm{~J} / \mathrm{cm} 2\end{array}$ & $\begin{array}{l}\text { Human osteoblast } \\
\text { cell line }\end{array}$ & Cell proliferation Differentiation & $\begin{array}{l}\text { LLLT } \\
\text { increased } \\
\text { cellular } \\
\text { proliferation } \\
\text { and } \\
\text { differentiation } \\
\text { of osteoblasts. } \\
\text { ALP activity } \\
\text { was twice } \\
\text { higher in } \\
\text { irradiated } \\
\text { group. }\end{array}$ \\
\hline 4 & $\begin{array}{c}\text { Wu et al. } 2012 \\
\text { (35) }\end{array}$ & $635 \mathrm{~nm}$ & $\begin{array}{l}\text { Single irradiation } \\
\text { Power: } 60 \mathrm{~mW} \\
\text { Fluence: } 0.5 \mathrm{~J} / \mathrm{cm} 2\end{array}$ & Murine bone marrow & Proliferation Gene expression & $\begin{array}{l}\text { Bone marrow } \\
\text { proliferation } \\
\text { was increased } \\
\text { significantly } \\
\text { by laser at } 2 \text {, } \\
4 \text {, and } 6 \text { days } \\
\text { later of } \\
\text { irradiation }\end{array}$ \\
\hline 5 & $\begin{array}{l}\text { Li et al. } 2006 \\
\text { (36) }\end{array}$ & 630 & $\begin{array}{l}\text { Single irradiation or } \\
\text { daily irradiation for } \\
5 \text { days Power: } 2.8 \text {, } \\
4.25 \text {, and } 8.86 \mathrm{~mW} \\
\text { Energy density: } 1.5 \\
\text { and } 2.5 \mathrm{~J} / \mathrm{cm} 2\end{array}$ & Murine bone marrow & Proliferation & $\begin{array}{l}\text { Single dose } \\
\text { irradiation did } \\
\text { not show } \\
\text { significant } \\
\text { increase in } \\
\text { cell } \\
\text { proliferation, } \\
\text { but daily doses } \\
\text { did at } 5 \text { days. }\end{array}$ \\
\hline 6 & $\begin{array}{l}\text { Hou et al. } 2008 \\
\text { (37) }\end{array}$ & $635 \mathrm{~nm}$ & $\begin{array}{l}\text { Single irradiation } \\
\text { Power: } 60 \mathrm{~mW} \\
\text { Fluence: } 0.5,1,2, \\
\text { and } 5 \mathrm{~J} / \mathrm{cm} 2\end{array}$ & Murine bone marrow & Proliferation & $\begin{array}{l}\text { Cellular } \\
\text { proliferation } \\
\text { was increased } \\
\text { significantly } \\
\text { by laser } \\
\text { irradiation and } \\
0.5 \mathrm{~J} / \mathrm{cm} 2 \text { was } \\
\text { optimal in this } \\
\text { regard. }\end{array}$ \\
\hline 7 & $\begin{array}{l}\text { Horvat-Karajz } \\
\text { et al. } 2009(38)\end{array}$ & $660 \mathrm{~nm}$ & $\begin{array}{l}\text { Power: } 60 \mathrm{~mW} \\
\text { Fluence: } 1.9 \text { and } 3.8 \\
\mathrm{~J} / \mathrm{cm} 2\end{array}$ & Murine bone marrow & Proliferation & $\begin{array}{l}\text { Lower doses } \\
\text { had } \\
\text { biostimulatory } \\
\text { effect in }\end{array}$ \\
\hline
\end{tabular}




\begin{tabular}{|c|c|c|c|c|c|c|}
\hline No & Author \& year & Type of laser & Type of irradiation & Type of cells & Criteria & Main results \\
\hline & & & & & & $\begin{array}{l}\text { adverse cell } \\
\text { proliferation } \\
\text { was inhibited } \\
\text { after } 48 \mathrm{~h} \text { at } \\
\text { higher doses } \\
(11.7 \mathrm{~J} / \mathrm{cm} 2)\end{array}$ \\
\hline 8 & $\begin{array}{l}\text { Giannelli et al. } \\
2013 \text { (39) }\end{array}$ & $635 \mathrm{~nm}$ & $\begin{array}{l}\text { Single irradiation } \\
\text { Power: } 89 \mathrm{~mW} \\
\text { Fluence: } 0.3 \mathrm{~J} / \mathrm{cm} 2\end{array}$ & Murine bone marrow & Proliferation & $\begin{array}{l}\text { Diode laser } \\
\text { increased cell } \\
\text { proliferation } \\
\text { significantly at } \\
72 \mathrm{~h} \text { after } \\
\text { irradiation }\end{array}$ \\
\hline 9 & $\begin{array}{l}\text { Wang et al. } \\
2012(40)\end{array}$ & $635 \mathrm{~nm}$ & $\begin{array}{l}\text { Single irradiation } \\
\text { Power: } 60 \mathrm{~mW} \\
\text { Fluence: } 0.5 \mathrm{~J} / \mathrm{cm} 2\end{array}$ & Murine bone marrow & Proliferation & $\begin{array}{l}\text { Laser } \\
\text { irradiation } \\
\text { promote } \\
\text { proliferation } \\
\text { process } 2 \text { and } \\
4 \text { days after of } \\
\text { exposure } \\
\text { compare to } \\
\text { control group. }\end{array}$ \\
\hline 10 & $\begin{array}{l}\text { Migliario et al. } \\
2014(41)\end{array}$ & $980 \mathrm{~nm}$ & $\begin{array}{l}\text { Continuous mode } \\
\text { Power outputs: } 1- \\
\text { 150 J Fluence: } 1.57 \text {, } \\
7.87,15.74,39.37 \\
\text { and } 78.75 \mathrm{~J} / \mathrm{cm} 2\end{array}$ & $\begin{array}{l}\text { Murine } \\
\text { preosteoblasts } \\
\text { MC3T3 cells }\end{array}$ & Cell proliferation & $\begin{array}{l}\text { LLLT } \\
\text { increased } \\
\text { proliferation } \\
\text { significantly } \\
\text { by } 515 \mathrm{~J} \\
\text { energy output. } \\
\text { While higher } \\
\text { energies (25- } \\
50 \mathrm{~J} \text { ) had } \\
\text { inhibitory } \\
\text { effect on the } \\
\text { osteoblast } \\
\text { proliferation. }\end{array}$ \\
\hline 11 & $\begin{array}{l}\text { Jawad et al. } \\
2013(42)\end{array}$ & $940 \mathrm{~nm}$ & $\begin{array}{l}\text { Continuous mode } \\
\text { Power outputs: } 100 \text {, } \\
\text { 200, } 300 \mathrm{~mW}\end{array}$ & $\begin{array}{l}\text { Human fetal } \\
\text { osteoblast cell line }\end{array}$ & $\begin{array}{l}\text { Proliferation Differantiation } \\
\text { (ALP and osteocalcin activity) }\end{array}$ & $\begin{array}{l}100 \text { and } 200 \\
\text { mW powers } \\
\text { promoted cell } \\
\text { differentiation } \\
\text { significantly } \\
\text { however } \\
300 \mathrm{~mW} \\
\text { stimulated } \\
\text { osteoblast } \\
\text { proliferation. }\end{array}$ \\
\hline 12 & $\begin{array}{l}\text { Renno et al. } \\
2010(26)\end{array}$ & $830 \mathrm{~nm}$ & $\begin{array}{l}\text { Single exposure } \\
\text { Power output: } \\
\text { 30mW Fluence: } 10 \\
\mathrm{~J} / \mathrm{cm} 2\end{array}$ & $\begin{array}{l}\text { Osteoblastic } \\
\text { (MC3T3) cell line }\end{array}$ & Proliferation & $\begin{array}{l}\text { Laser } \\
\text { irradiation } \\
\text { reduced } \\
\text { osteoblast } \\
\text { proliferation } \\
\text { compared to } \\
\text { control group. }\end{array}$ \\
\hline 13 & $\begin{array}{l}\text { Bouvet- } \\
\text { Gerbettaz et al. } \\
2009(27)\end{array}$ & $808 \mathrm{~nm}$ & $\begin{array}{l}\text { Continuous mode } \\
\text { Fluence: } 4 \mathrm{~J} / \mathrm{cm} 2 \\
\text { Three times a week }\end{array}$ & $\begin{array}{l}\text { Murine bone marrow } \\
\text { cell }\end{array}$ & $\begin{array}{l}\text { Bone cell proliferation, } \\
\text { Osteoblastic and osteoclastic } \\
\text { differentiation }\end{array}$ & $\begin{array}{l}\text { Infrared laser } \\
\text { did not alter } \\
\text { proliferation } \\
\text { and } \\
\text { differentiation } \\
\text { compared to } \\
\text { control group }\end{array}$ \\
\hline 14 & $\begin{array}{l}\text { Hamajima et } \\
\text { al. } 2003(43)\end{array}$ & $830 \mathrm{~nm}$ & $\begin{array}{l}\text { Continuous mode } \\
\text { Power output: } 500 \\
\text { mW Fluence: } 7.64 \\
\mathrm{~J} / \mathrm{cm} 2\end{array}$ & $\begin{array}{l}\text { Mouse calvaria } \\
\text { derived osteoblastic } \\
\text { cell line, MC3T3-E1 }\end{array}$ & Bone formation & $\begin{array}{l}\text { Diode laser } \\
\text { can promote } \\
\text { bone } \\
\text { formation by } \\
\text { increasing } \\
\text { osteoglycin } \\
\text { expression }\end{array}$ \\
\hline 15 & Tuby et al. (44) & $804 \mathrm{~nm}$ & $\begin{array}{l}\text { Single irradiation } \\
\text { Power: } 400 \mathrm{~mW}\end{array}$ & Murine bone marrow & Cell proliferation & $\begin{array}{l}\text { LLLT } \\
\text { promoted }\end{array}$ \\
\hline
\end{tabular}




\begin{tabular}{|c|c|c|c|c|c|c|c|}
\hline \multirow{3}{*}{ 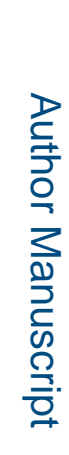 } & No & Author \& year & Type of laser & Type of irradiation & Type of cells & Criteria & Main results \\
\hline & & & & $\begin{array}{l}\text { Fluence: } 1 \text { and } 3 \\
\mathrm{~J} / \mathrm{cm} 2\end{array}$ & & & $\begin{array}{l}\text { MSCs } \\
\text { proliferation at } \\
\text { all intervals } \\
\text { for both doses } \\
\text { studied ( } 1 \text { and } \\
3 \mathrm{~J} / \mathrm{cm} 2)\end{array}$ \\
\hline & 16 & $\underset{(45)}{\text { Soleimani et al. }}$ & $810 \mathrm{~nm}$ & $\begin{array}{l}1,3 \text {, and } 5 \text { days } \\
\text { after incubation } \\
\text { Power: } 50 \mathrm{~mW} \\
\text { Fluence: } 2 \text { and } 4 \\
\mathrm{~J} / \mathrm{cm} 2\end{array}$ & Human bone marrow & Proliferation Differentiation & $\begin{array}{l}\text { Cell } \\
\text { proliferation } \\
\text { was enhanced } \\
\text { by doses of } 2 \text {, } \\
3 \text {, and } 4 \mathrm{~J} / \mathrm{cm} 2 \\
\text { but } 6 \mathrm{~J} / \mathrm{cm} 2 \\
\text { gave no } \\
\text { difference. } \\
\text { ALP activity } \\
\text { was increased } \\
\text { significantly } \\
\text { by laser } \\
\text { irradiation. }\end{array}$ \\
\hline 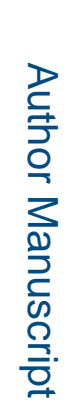 & 17 & $\begin{array}{l}\text { Fekrazad et al } \\
2015(11)\end{array}$ & $810 \mathrm{~nm}$ & $\begin{array}{l}\text { Power: } 200 \mathrm{~mW} \\
\text { Fluence: } 4 \mathrm{~J} / \mathrm{cm} 2 \\
\text { Power density: } 0.2 \\
\mathrm{~W} / \mathrm{cm}^{2} 20 \mathrm{sec} \text { per } \\
\text { day for } 3 \text { week }\end{array}$ & $\begin{array}{l}\text { Rabbit bone marrow } \\
\text { mesenchymal stem } \\
\text { cells }\end{array}$ & $\begin{array}{l}\text { Healing of artificial calvarial } \\
\text { defects }\end{array}$ & $\begin{array}{l}\text { LLLT } \\
\text { significantly } \\
\text { increased new } \\
\text { bone } \\
\text { formation } \\
\text { relative to } \\
\text { control group } \\
\text { but had no } \\
\text { synergistic } \\
\text { effect in } \\
\text { conjunction } \\
\text { with MSCs in } \\
\text { bone } \\
\text { formation. }\end{array}$ \\
\hline$\stackrel{D}{\stackrel{D}{\rightleftarrows}}$ & 18 & $\begin{array}{l}\text { Fekrazad et al } \\
2016(7)\end{array}$ & $810 \mathrm{~nm}$ & $\begin{array}{l}\text { Power: } 30 \mathrm{~mW} \\
\text { Fluence: } 8.5 \mathrm{~J} / \mathrm{cm} 2 \\
20 \mathrm{sec} \text { per day for } 3 \\
\text { week }\end{array}$ & $\begin{array}{l}\text { Rabbit bone marrow } \\
\text { mesenchymal stem } \\
\text { cells }\end{array}$ & $\begin{array}{l}\text { Healing of artificial } \\
\text { osteochondral defects }\end{array}$ & $\begin{array}{l}\text { There was } \\
\text { better healing } \\
\text { by LLLT } \\
\text { compared with } \\
\text { BMSCs alone, } \\
\text { with higher } \\
\text { bone } \\
\text { formation } \\
\text { rather than } \\
\text { cartilage } \\
\text { formation }\end{array}$ \\
\hline 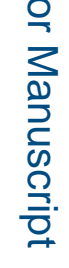 & 19 & $\begin{array}{l}\text { Aleksic et al. } \\
2010(46)\end{array}$ & $\begin{array}{l}\text { Er: YAG } \\
\text { laser }(2940 \\
\mathrm{nm})\end{array}$ & $\begin{array}{l}\text { Pulsed radiation } \\
\text { Energy/pulse } \\
\text { output: } 30-350 \mathrm{~mJ} \\
\text { Fluence: } 0.7-17.2 \\
\mathrm{~J} / \mathrm{cm} 2\end{array}$ & $\begin{array}{l}\text { Mouse-derived } \\
\text { osteoblastic cell line } \\
\text { MC3T3-E1 }\end{array}$ & $\begin{array}{l}\text { Cell proliferation Cell death } \\
\text { Mitogen-activated protein } \\
\text { kinase (MAPK) pathways }\end{array}$ & $\begin{array}{l}\text { Er: YAG laser } \\
\text { may be able to } \\
\text { promote bone } \\
\text { healing } \\
\text { following } \\
\text { periodontal } \\
\text { and peri } \\
\text { implant } \\
\text { therapy. }\end{array}$ \\
\hline
\end{tabular}

